\title{
Cell-specific delivery using an engineered protein nanocage
}

\author{
Mikail D. Levasseur, ${ }^{\dagger}$ Shiksha Mantri, ${ }^{\dagger}$ Takahiro Hayashi, Maria Reichenbach, Svenja Hehn, Ying \\ Waeckerle-Men, Pål Johansen, and Donald Hilvert*
}

† These authors contributed equally to this work

* correspondence to hilvert@org.chem.ethz.ch

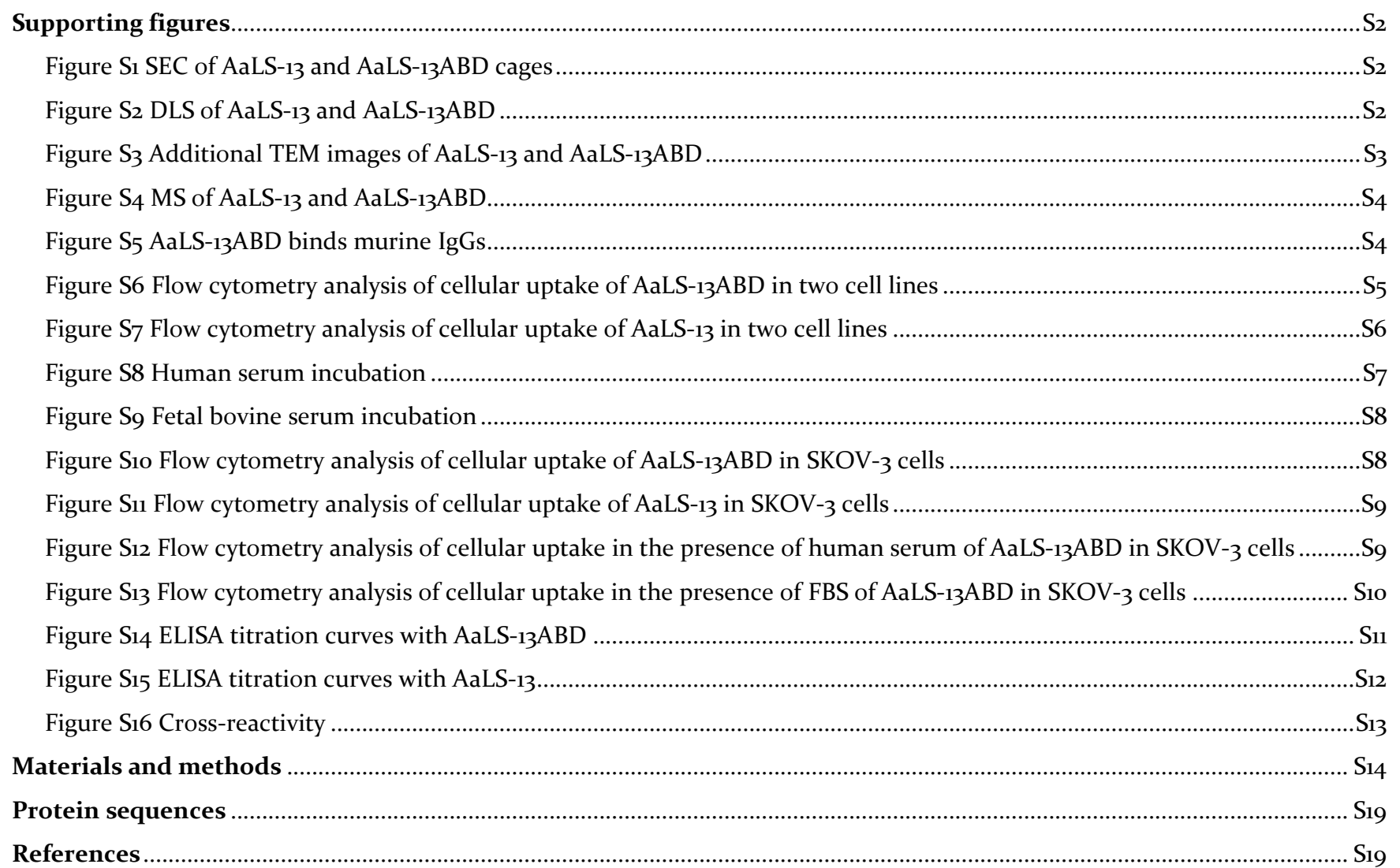




\section{Supporting figures}

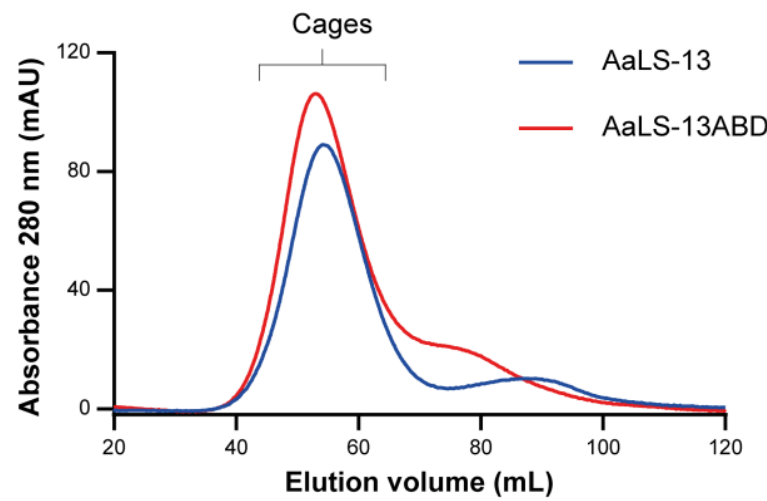

Figure S1 SEC of AaLS-13 and AaLS-13ABD cages. The crude mixture after Ni-NTA affinity chromatography is shown.

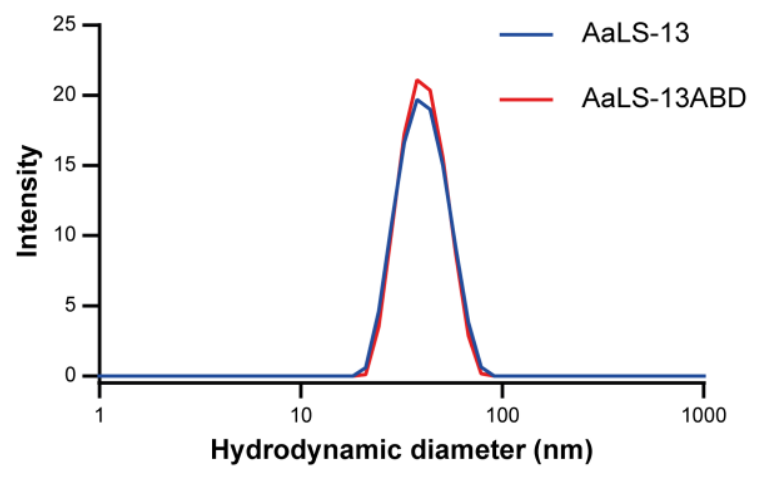

Figure S2 DLS of AaLS-13 and AaLS-13ABD. The crude mixture after Ni-NTA affinity chromatography is shown. Measurements confirmed that AaLS-13 (average diameter $=38.8 \mathrm{~nm} ; \mathrm{PDI}=0.061$ ) and AaLS-13ABD (average diameter $=39.1 \mathrm{~nm} ; \mathrm{PDI}=0.043$ ) have similar average diameters. 

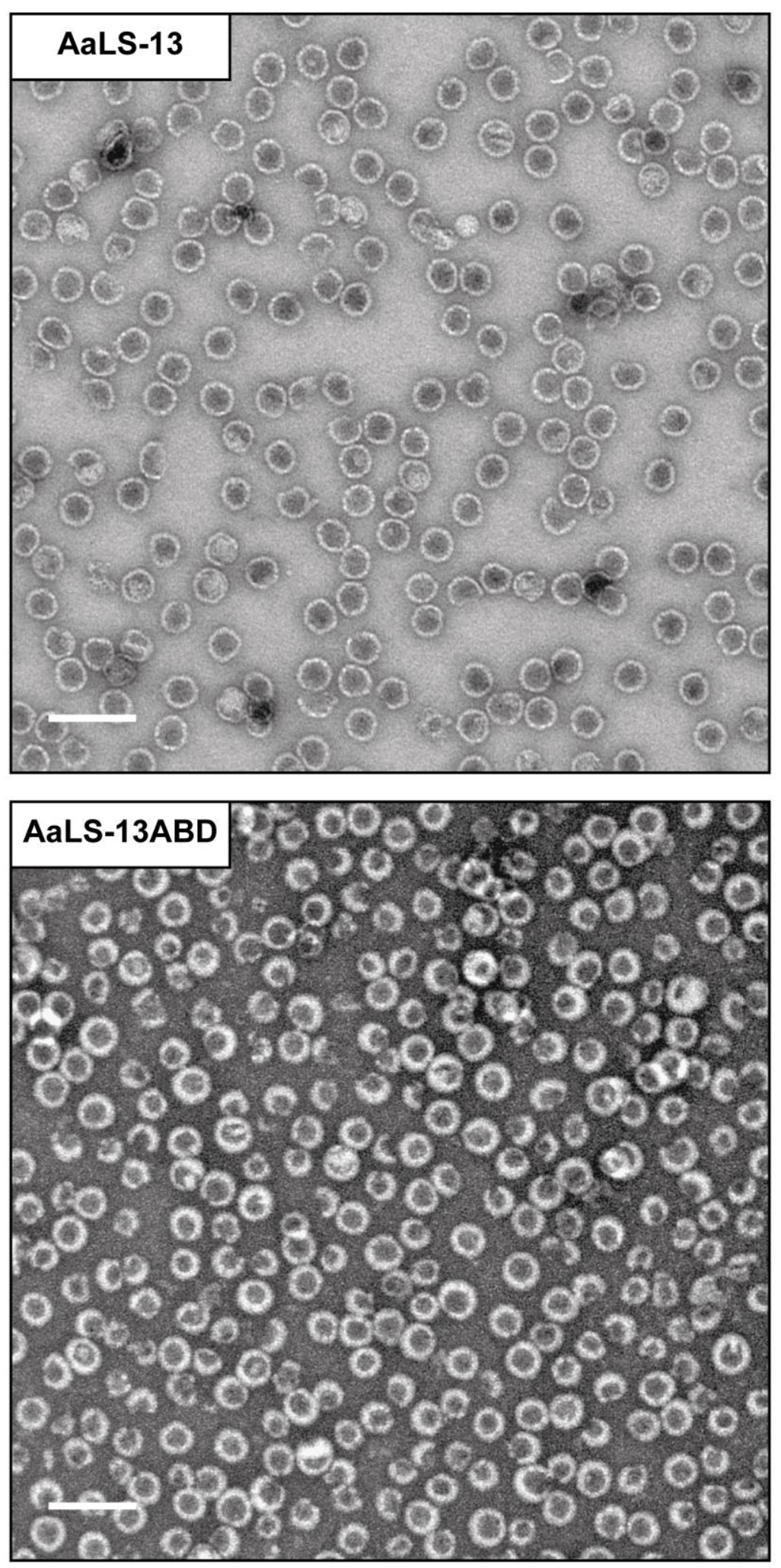

Figure $S_{3}$ Additional TEM images of AaLS-13 and AaLS-13ABD. The AaLS-13ABD diameter was determined to be $37.3 \pm 2.5 \mathrm{~nm}$ (mean \pm standard deviation), which is similar to AaLS-13 $(36.1 \pm 1.8 \mathrm{~nm})$. Scale bars $=100 \mathrm{~nm}$. 
a

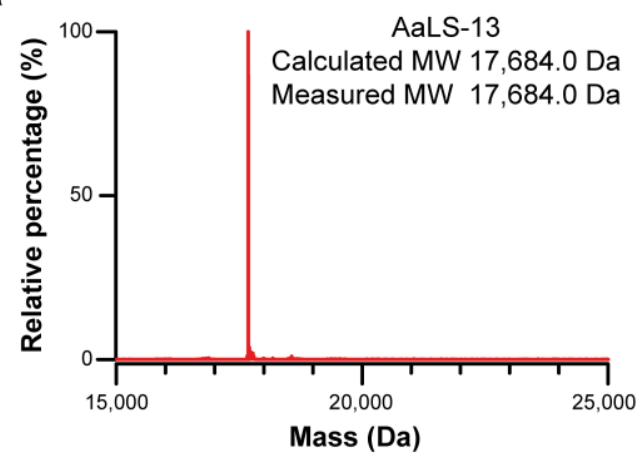

b

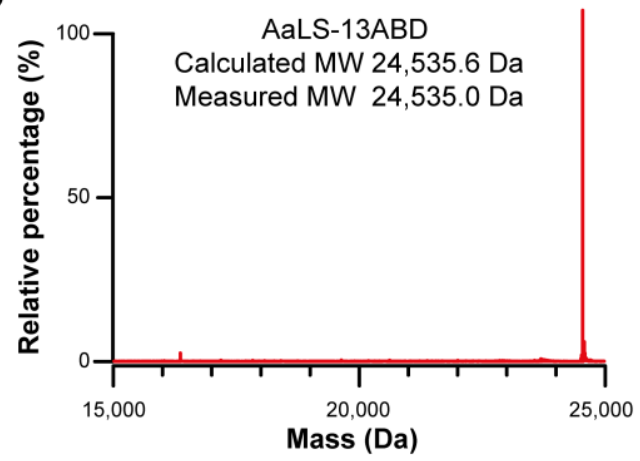

Figure S $_{4}$ MS of AaLS-13 and AaLS-13ABD. The measured masses match the calculated ones indicating that the ABD peptide was successfully displayed on each AaLS-13 subunit.

a

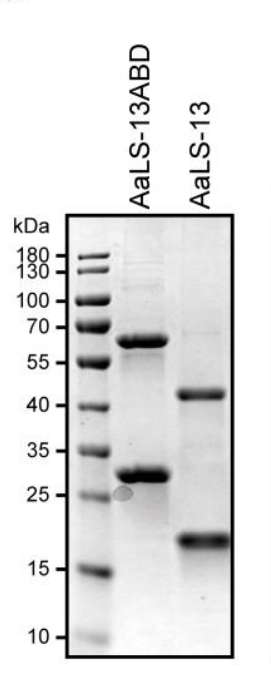

b

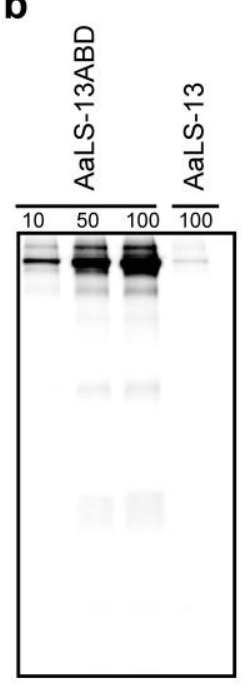

Figure S5 AaLS-13ABD binds murine IgGs. AaLS-13ABD was incubated with 10, 50, or 100 mouse serum IgG molecules per cage for 1 hour at room temperature. The complexes were purified by Ni-NTA chromatography and analyzed by Sodium dodecyl sulfate-polyacrylamide gel electrophoresis (SDS-PAGE). a) Coomassie-stained SDS-PAGE and b) in-gel fluorescence confirmed that the high molecular weight species correspond to the carboxyfluorescein-labeled mouse serum IgGs. All SDS-PAGE samples were prepared without reducing disulfide bridges in order to observe full-length antibodies, which also explains why dimeric species are present. 


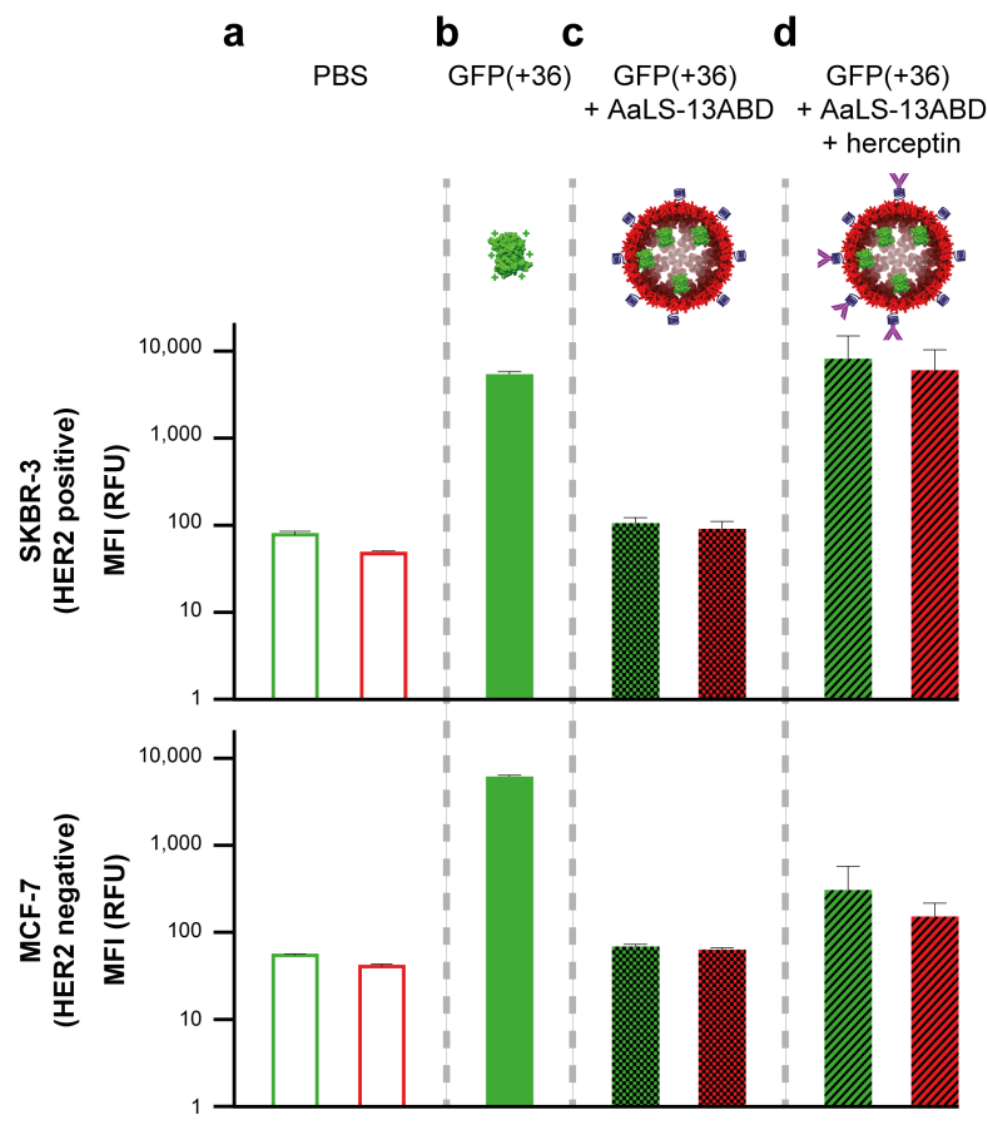

Figure S6 Flow cytometry analysis of cellular uptake of AaLS-13ABD in two cell lines. a) Background fluorescence intensity from untreated cells. Cellular uptake of b) free GFP $(+36)$ and GFP $(+36)$ encapsulated in ATTO-565-labeled AaLS-13ABD c) in the absence or $d$ ) presence of herceptin as determined by flow cytometry. Top: uptake into HER2-positive cell line SKBR-3. Bottom: uptake into HER2-negative cell line MCF-7. Error bars are the standard deviation from three replicates. Green and red bars represent median fluorescence intensity signals from $\mathrm{GFP}(+36)$ and ATTO-565 labeled AaLS-13ABD, respectively. 


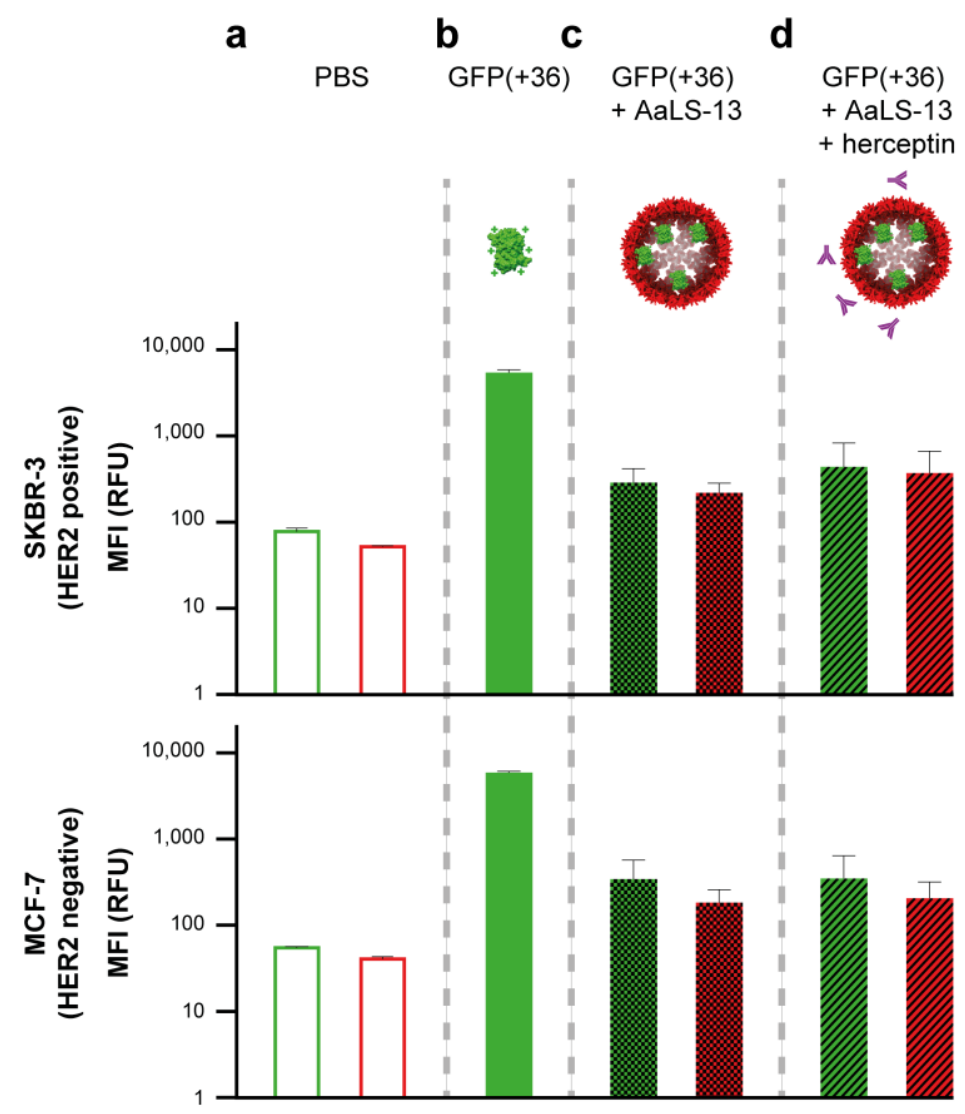

Figure $\mathbf{S}_{7}$ Flow cytometry analysis of cellular uptake of AaLS-13 in two cell lines. a) Background fluorescence intensity from untreated cells. Cellular uptake of b) free GFP $(+36)$, and GFP $(+36)$ encapsulated in ATTO-565 labeled AaLS-13 c) in absence or d) presence of Herceptin as determined by flow cytometry. Top: uptake into HER2-positive cell line SKBR-3. Bottom: uptake into HER2-negative cell line MCF-7. Error bars are the standard deviation from three replicates. Green and red bars represent median fluorescence intensity signals from GFP $(+36)$ and ATTO-565 labeled AaLS-13, respectively. 
a

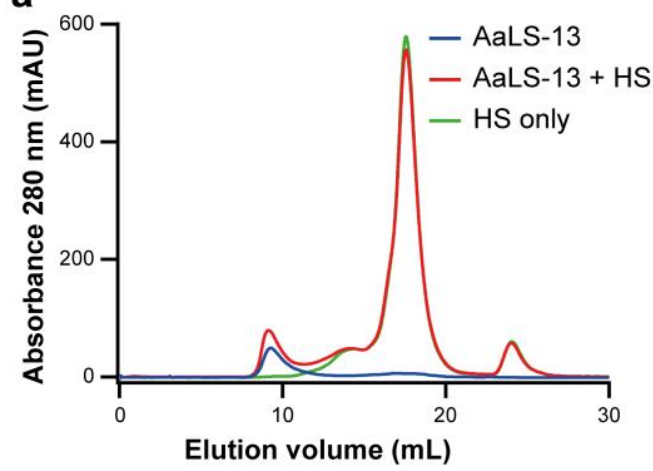

b

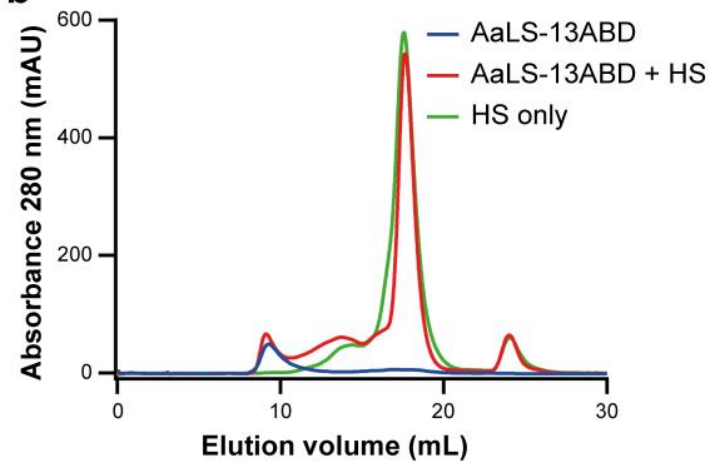

C

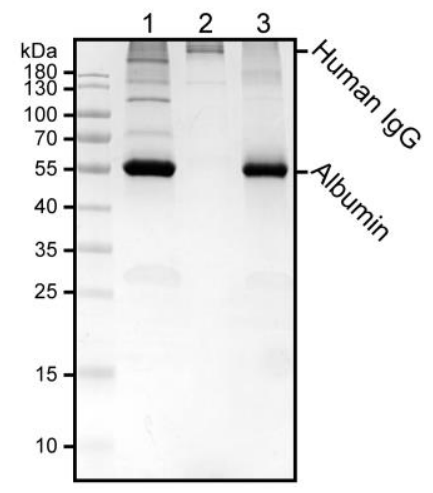

d

e
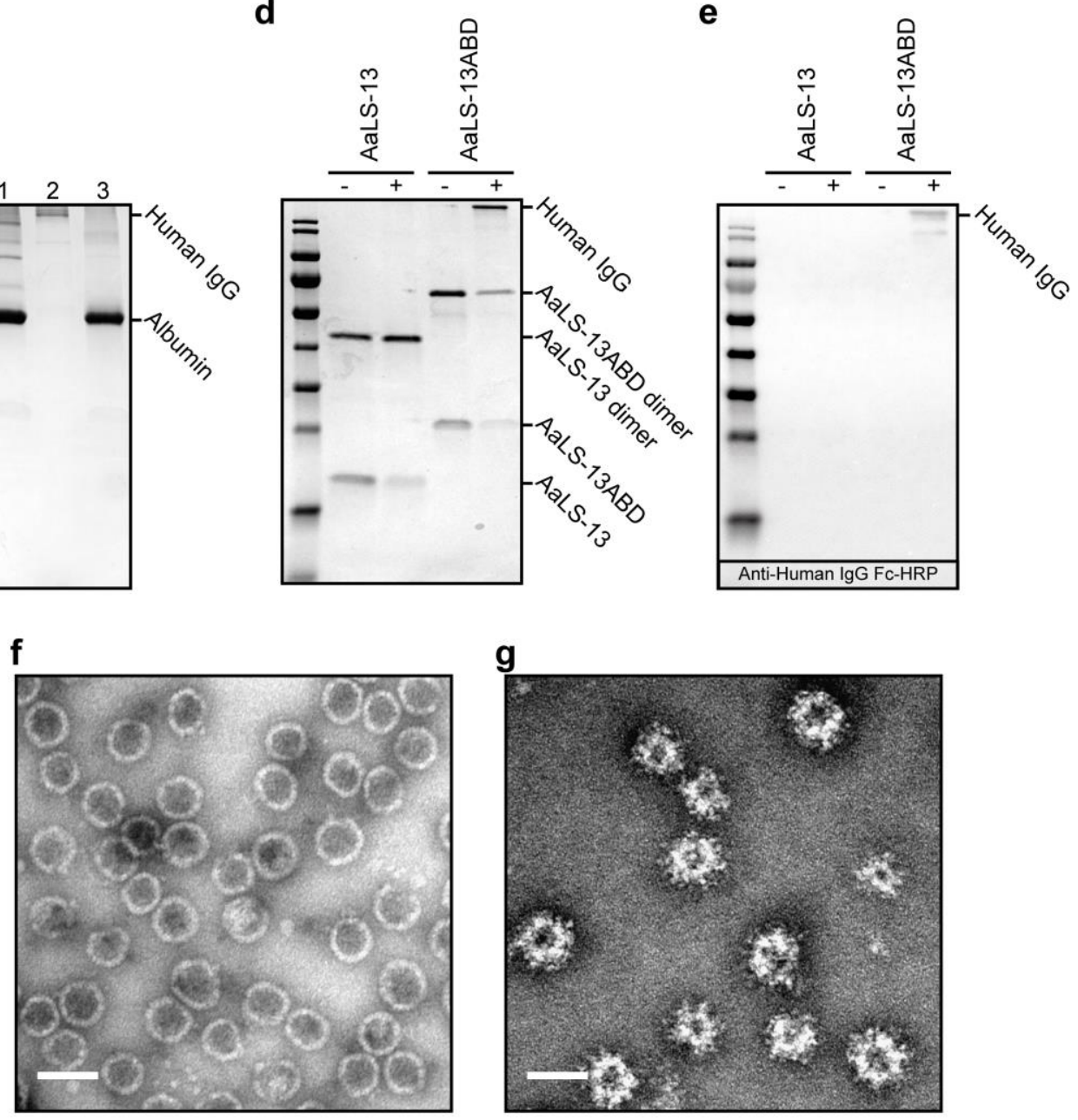

g

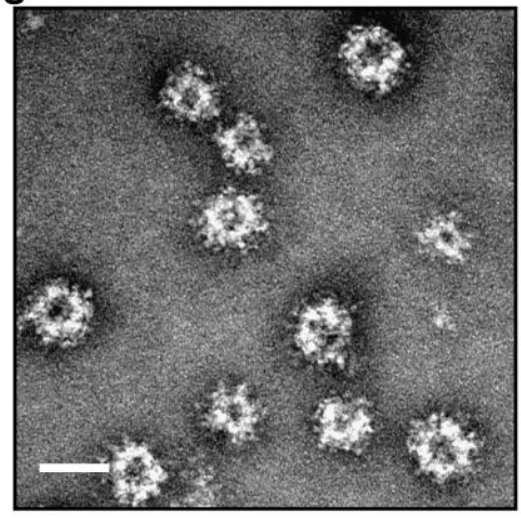

Figure S8 Human serum incubation. Size exclusion chromatograms of a) AaLS-13 and b) AaLS-13ABD cages after incubation in human serum for 18 hours at $37^{\circ} \mathrm{C}$. c) SDS-PAGE analysis of human serum composition. Lane 1: crude serum, lane 2: elution peak at $14 \mathrm{~mL}$, lane 3: elution peak at $18 \mathrm{~mL}$. Capsid peaks (at $9 \mathrm{~mL}$ ) were pooled, concentrated, and analyzed by d) SDS-PAGE and e) Western Blot using an anti-human IgG Fc-HRP antibody. TEM images of SEC-purified f) AaLS-13 and g) AaLS-13ABD cages after incubation in human serum. Scale bars $=50 \mathrm{~nm}$. All SDS-PAGE samples were prepared without reducing disulfide bridges in order to observe full-length antibodies, which also explains why dimeric species are present. 
a

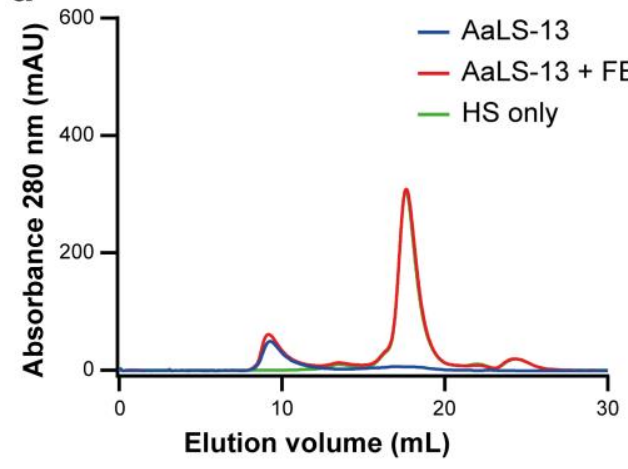

C b

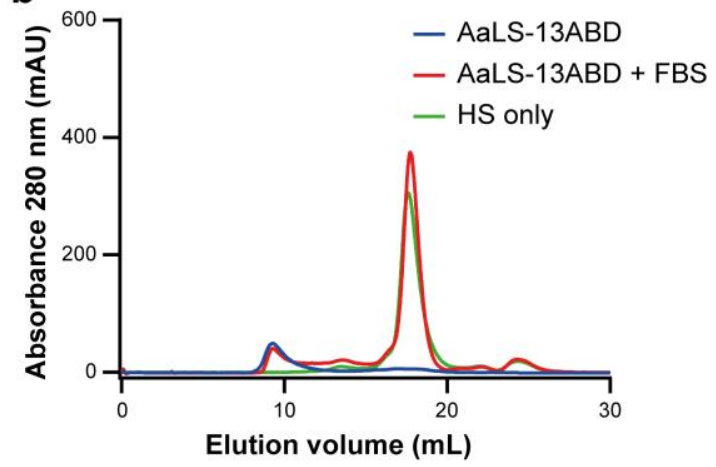

d

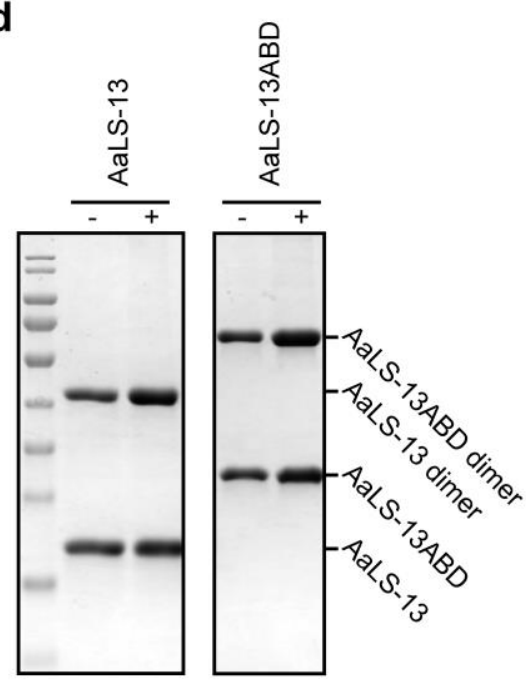

Figure S9 Fetal bovine serum incubation. Size exclusion chromatograms of a) AaLS-13 and b) AaLS-13ABD cages after incubation in fetal bovine serum for 18 hours at $37^{\circ} \mathrm{C}$. c) SDS-PAGE analysis of fetal bovine serum composition. Lane 1: crude serum, lane 2 : elution peak at $14 \mathrm{~mL}$, lane 3: elution peak at $18 \mathrm{~mL}$. The capsid peaks (at $9 \mathrm{~mL}$ ) were isolated and analyzed by d) SDS-PAGE. All SDS-PAGE samples were prepared without reducing disulfide bridges in order to observe full-length antibodies, which also explains why dimeric species are present.

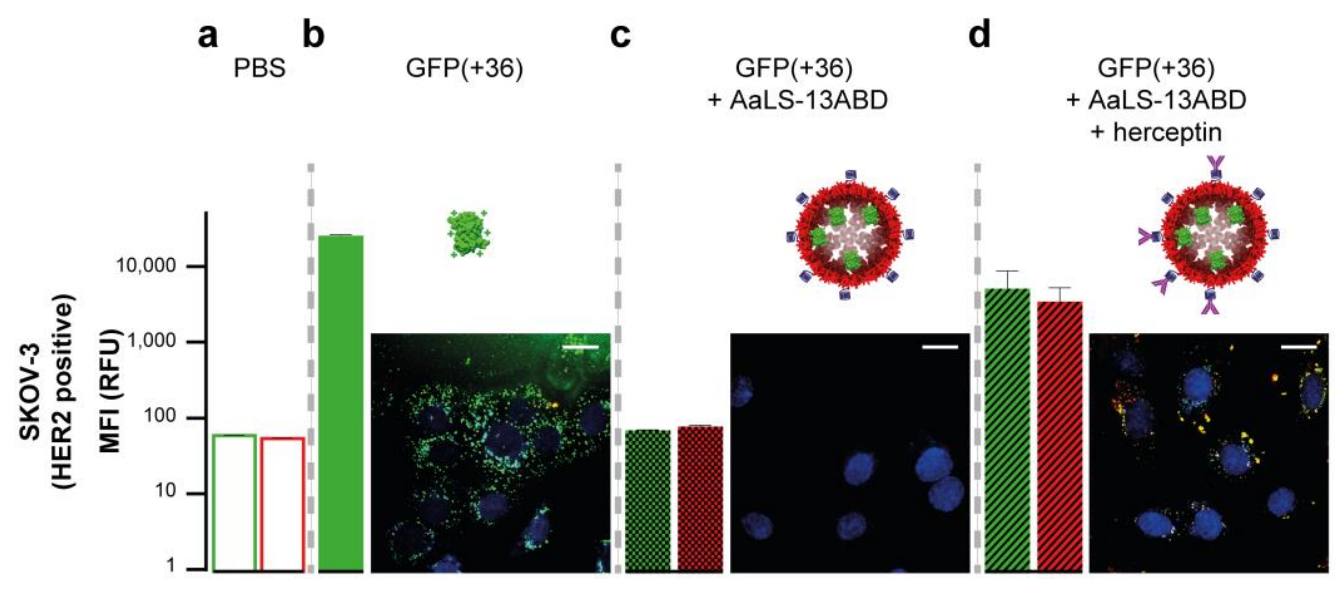

Figure S1o Flow cytometry analysis of cellular uptake of AaLS-13ABD in SKOV-3. a) Background fluorescence intensity from buffer (PBS). Cellular uptake of b) free GFP(+36) and GFP(+36) encapsulated in ATTO-565 labeled AaLS-13ABD c) in absence or d) presence of herceptin by SKOV-3 cells, determined by flow cytometry and confocal microscopy. Error bars are the standard deviation from three replicates. Green and red bars represent median fluorescence intensity signals from GFP(+36) and ATTO565 labeled AaLS-13ABD, respectively. Hoechst 33342 staining was used to visualize the nucleus (blue). Overlap of the green and the red channel signals were visualized as yellow, indicating co-localization of GFP(+36) and ATTO-565 labeled AaLS-13ABD. Scale bars: $10 \mu \mathrm{m}$. 


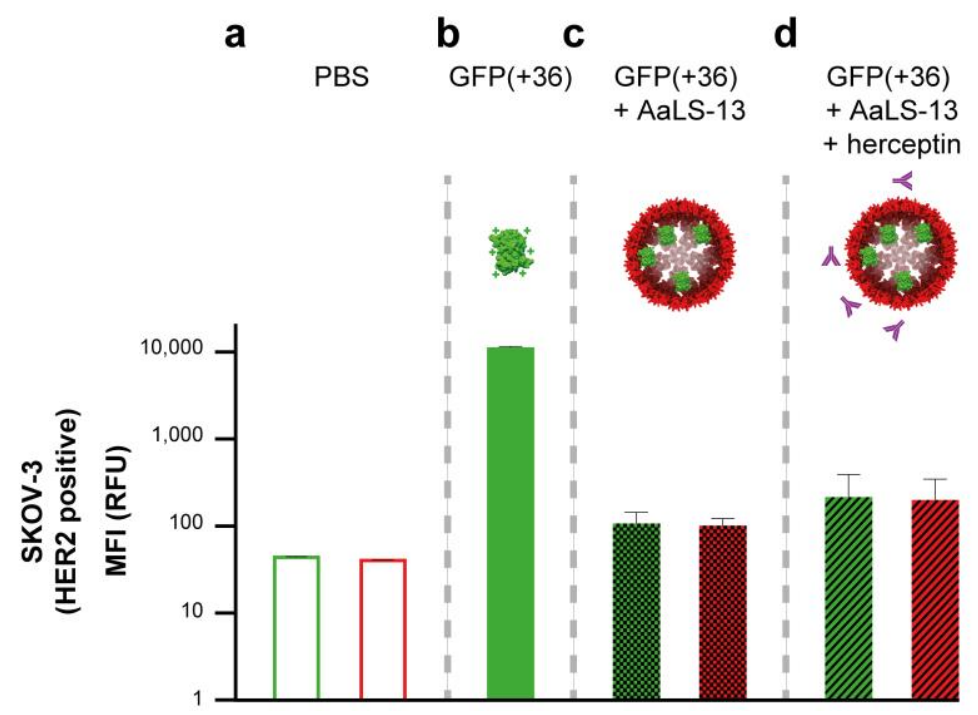

Figure S11 Flow cytometry analysis of cellular uptake of AaLS-13 in SKOV-3 cells. a) Background fluorescence intensity from untreated cells. Cellular uptake of b) free GFP $(+36)$ and GFP $(+36)$ encapsulated in ATTO-565 labeled AaLS-13 c) in absence or d) presence of herceptin by SKOV-3 cells, determined by flow cytometry. Error bars are the standard deviation from 3 replicates. Green and red bars represent median fluorescence intensity signals from GFP(+36) and ATTO-565 labeled AaLS-13, respectively.

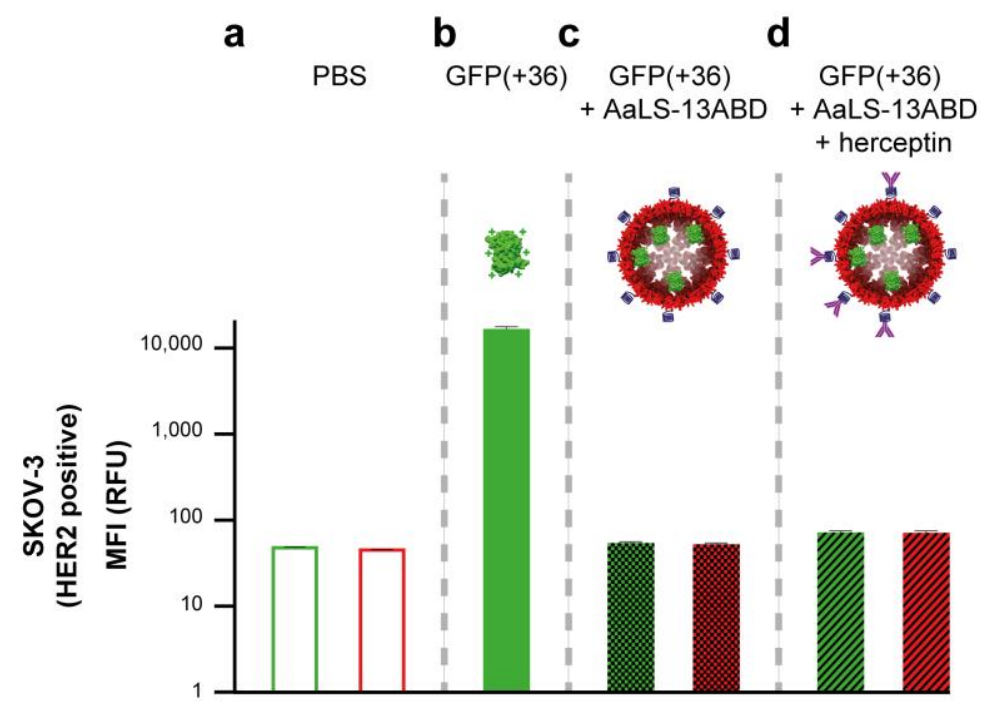

Figure S12 Flow cytometry analysis of cellular uptake in the presence of human serum of AaLS-13ABD in SKOV-3 cells. a) Background fluorescence intensity from untreated cells. Cellular uptake of b) free GFP(+36) and GFP(+36) encapsulated in ATTO-565 labeled AaLS-13ABD c) in absence or d) presence of herceptin in human serum-containing medium by SKOV-3 cells, determined by flow cytometry. Error bars are the standard deviation from 3 replicates. Green and red bars represent median fluorescence intensity signals from GFP(+36) and ATTO-565 labeled AaLS-13ABD, respectively. 


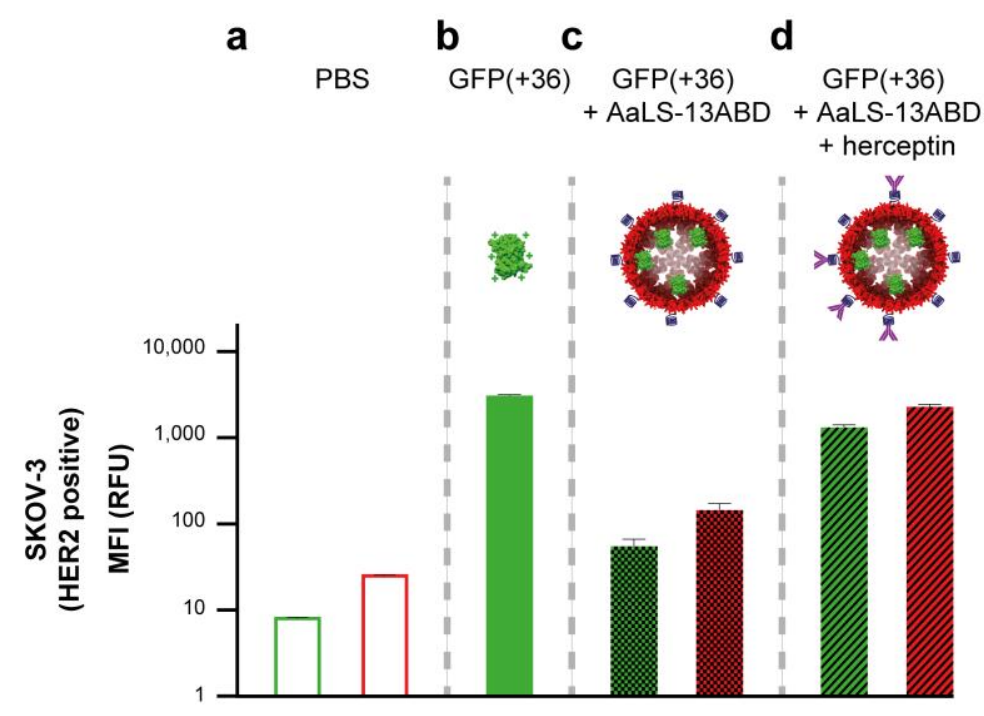

Figure S13 Flow cytometry analysis of cellular uptake in the presence of FBS of AaLS-13ABD in SKOV-3 cells. a) Background fluorescence intensity from untreated cells. Cellular uptake of b) free GFP(+36) and GFP(+36) encapsulated in ATTO-565 labeled AaLS-13ABD c) in absence or d) presence of herceptin in fetal bovine serum-containing medium by SKOV-3 cells, determined by flow cytometry. Error bars are the standard deviation from 3 replicates. Green and red bars represent median fluorescence intensity signals from $\mathrm{GFP}(+36)$ and ATTO-565 labeled AaLS-13ABD, respectively. 
$0.2 \mu g$ AaLS-13ABD
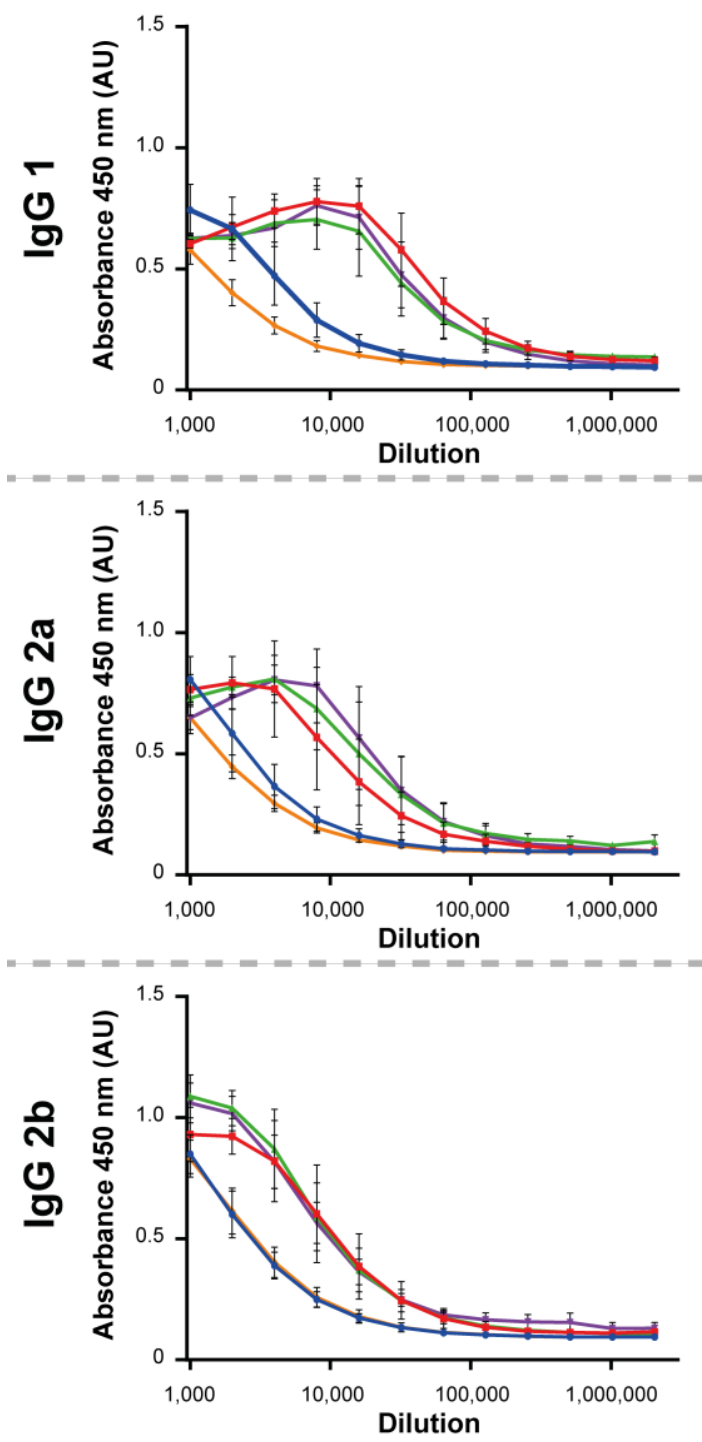

\section{$1.0 \mu g$ AaLS-13ABD}
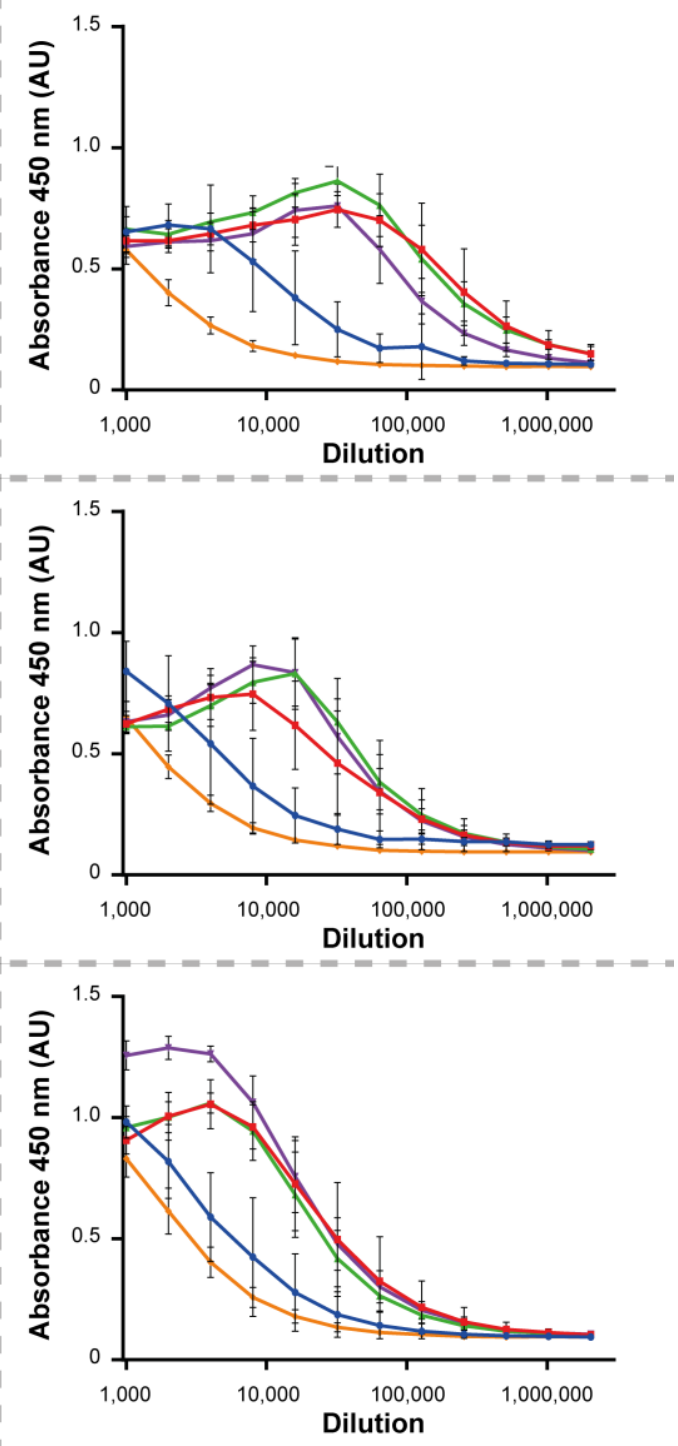

$\rightarrow$ Day $0 \rightarrow$ Day $14 \rightarrow$ Day $29 \rightarrow$ Day $52 \rightarrow$ Day 72

Figure S14 ELISA titration curves with AaLS-13ABD. ELISA titration curves of serum from mice immunized with o.2 $\mu \mathrm{g}$ and $1 \mu \mathrm{g}$ AaLS-13ABD cages. The average optical density at $450 \mathrm{~nm}$ of blood collections from 8 different mice is shown. Error bars indicate standard deviation. The large response seen before immunization (day o) reflects binding of antibodies to the ABD element via their Fc fragment. As a consequence, the curves obtained after immunization appear right shifted compared to their AaLS-13 counterparts (Figure $\mathrm{S}_{15}$ ). 

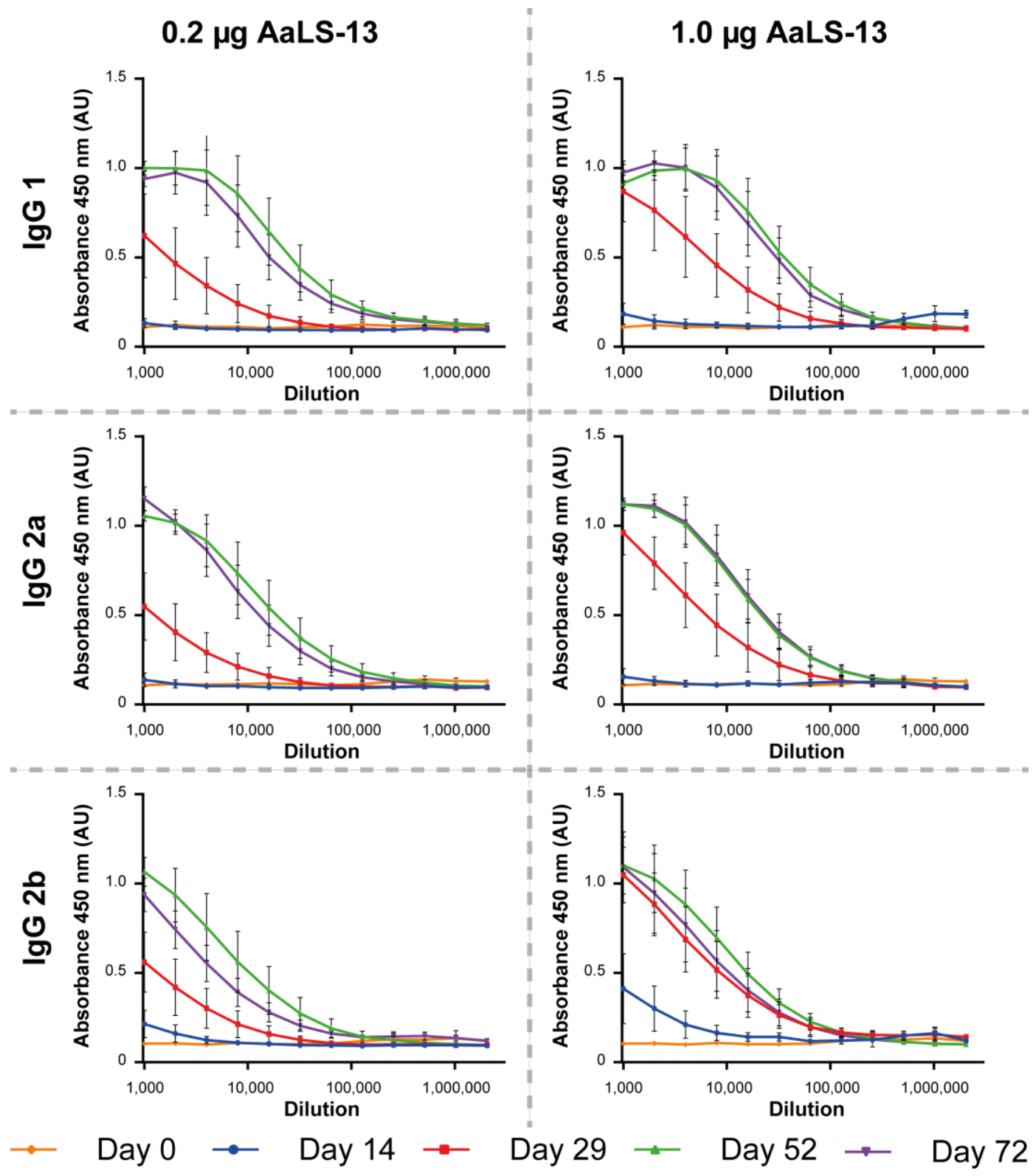

Figure S15 ELISA titration curves with AaLS-13. ELISA titration curves of serum from mice immunized with $0.2 \mu \mathrm{g}$ and $1 \mu \mathrm{g}$ AaLS13 cages. The average optical density at $450 \mathrm{~nm}$ of blood collections from 8 different mice is shown. Error bars indicate standard deviation. 
AaLS-13ABD-coated plates
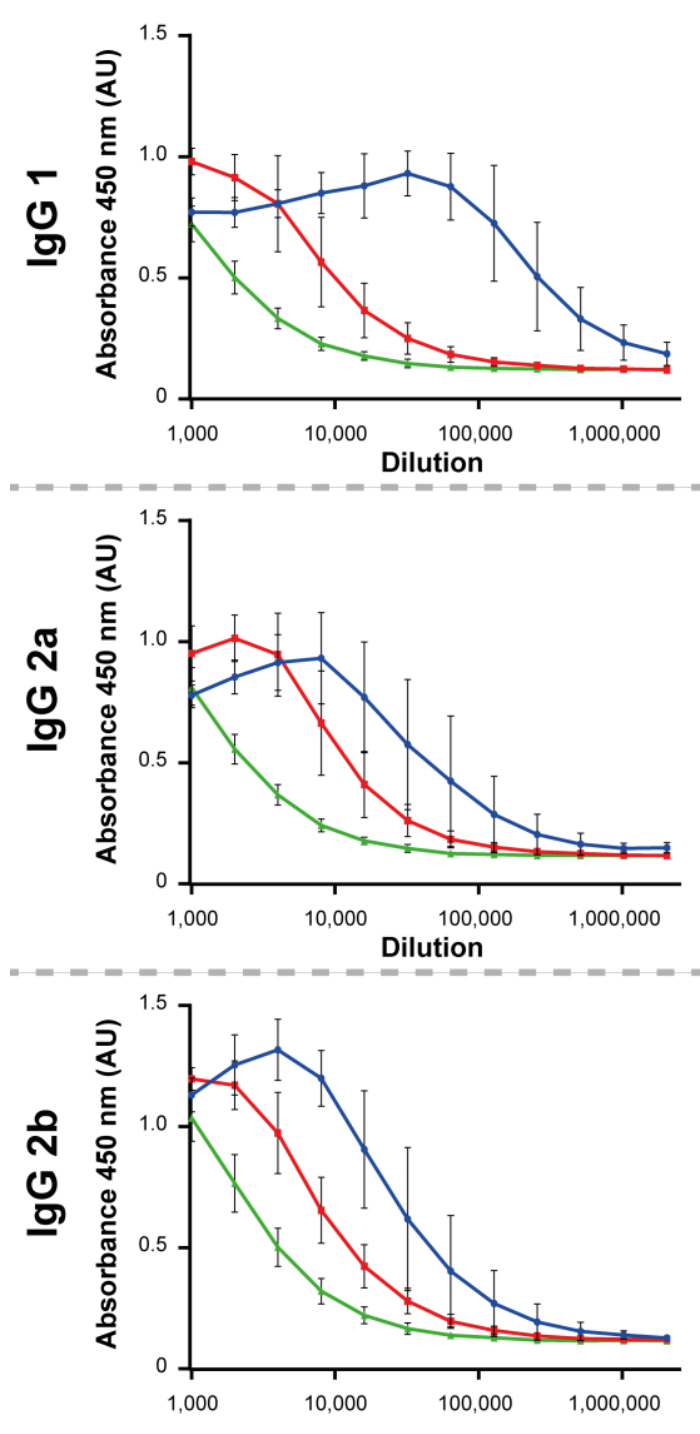

$\rightarrow$ AaLS-13ABD sera
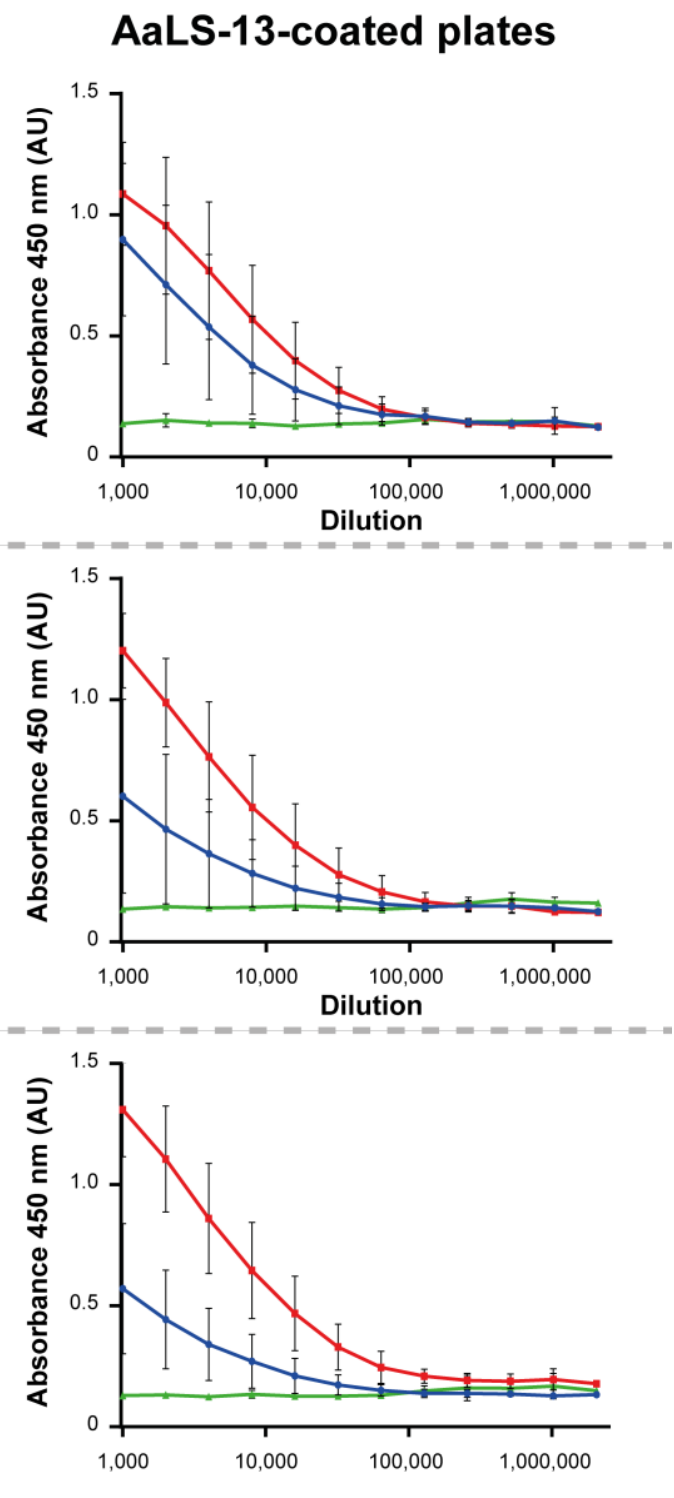

Figure S16 Cross-reactivity. ELISA titration curves of serum from mice immunized with $1 \mu$ g AaLS-13ABD and AaLS-13 cages. Serum samples from day 52 were chosen. The average optical density at $450 \mathrm{~nm}$ of blood collections from 8 different mice is shown. Error bars indicate standard deviation. 


\section{Materials and methods}

\section{Materials and instrumentation}

All restriction enzymes, $\mathrm{T}_{4}$ polynucleotide kinase (PNK), Phusion ${ }^{\circledR}$ High-Fidelity DNA polymerase, and $\mathrm{T}_{4}$ DNA ligase were obtained from New England BioLabs. Oligonucleotides were synthesized by Microsynth AG. Isopropyl $\beta$-D-1-thiogalactopyranoside (IPTG) was purchased from Fluorochem. Ethylenediaminetetraacetic acid (EDTA) was purchased from AppliChem $\mathrm{GmbH}$. All other buffer components and salts were purchased from Merck KGaA or Fisher Scientific. The supercharged GFP variant was produced and purified as previously described. ${ }^{1}$ Herceptin was obtained from Genentech. Human breast adenocarcinoma cell lines SKBR-3 and MCF-7, as well as the human ovarian adenocarcinoma cell line SKOV-3, were obtained from American Type Culture Collection. Human serum samples were obtained from Interregionale Blutspende SRK AG.

DNA and protein quantification were carried out using a NanoDrop 200oc spectrophotometer from ThermoFisher Scientific Inc. All size-exclusion chromatography was carried out on an NGCTM Medium-Pressure Chromatography System from Bio-Rad Laboratories, Inc. Transmission electron microscopy (TEM) images were obtained on a Morgagni 268 from FEI. Flow cytometry was carried out on an LSRFortessa from BD Biosciences.

\section{Construction of AaLS-13ABD}

To ensure $E$. coli expression, the DNA sequence of the antibody binding domain (VDNKFNKEQQNAFYEILHLPNLNEEQRNAFIQSLKDDPSQSANLLAEAKKLNDAQAPK) was optimized using the online codon optimizing tool - OPTIMIZER (http://genomes.urv.es/OPTIMIZER): 5'-GTTGACA ACAAATTCAACAAAGAACAGCAGAACGCGTTCTACGAAATCCTGCACCTGCCGAACCTGAACGAAGAA CAGCGTAACGCGTTCATCCAGTCTCTGAAAGACGACCCGTCTCAGTCTGCGAACCTGCTGGCGGAAGC GAAAAAACTGAACGACGCGCAGGCGCCGAAA.

The following oligonucleotides were used to assemble a DNA fragment containing a NotI and SpeI restriction site at the 5' and 3', respectively, using gene assembly PCR:

1. 5'ATTAAGGCCGCCGTTGACAACAAATTCAACAAAGAACAG

2. 5’ATTTCGTAGAACGCGTTCTGCTGTTCTTTGTTGAATTTG

3. 5'-ACGCGTTCTACGAAATCCTGCACCTGCCGAACCTGAACG

4. 5'-GATGAACGCGTTACGCTGTTCTTCGTTCAGGTTCGGCAG 
5. 5'-GTAACGCGTTCATCCAGTCTCTGAAAGACGACCCGTCTC

\section{5'-TTCCGCCAGCAGGTTCGCAGACTGAGACGGGTCGTCTTT}

\section{5'-CCTGCTGGCGGAAGCGAAAAAACTGAACGACGCGCAGG}

\section{5'-TATATTACTAGTTTATCATTTCGGCGCCTGCGCGTCGTT}

The PCR product was purified, digested with the restriction enzymes SpeI and NotI, and ligated into a pMG211 vector ${ }^{2}$ encoding a modified AaLS-13 gene equipped with a NotI restriction site following the hexahistidine tag.

\section{Protein expression and purification}

AaLS-13ABD was expressed in E. coli strain BL21-Gold (DE3) containing the pMG211-AaLS-13ABD plasmid. Cells were grown at $37^{\circ} \mathrm{C}$ in $\mathrm{LB}$ medium until the OD6oo reached $\sim 0.6$, at which point protein production was induced by adding IPTG to a final concentration of $0.1 \mathrm{mM}$. After culturing at $25^{\circ} \mathrm{C}$ for 22 hours, cells were harvested by centrifugation at $5,000 \mathrm{~g}$ and $4{ }^{\circ} \mathrm{C}$ for $10 \mathrm{~min}$. The cell pellet was stored at $-20{ }^{\circ} \mathrm{C}$ until purification. The cell pellet from a $400 \mathrm{~mL}$ culture was re-suspended in $20 \mathrm{~mL}$ lysis buffer ( $50 \mathrm{mM}$ sodium phosphate (pH 8.0), $300 \mathrm{mM} \mathrm{NaCl}, 10 \mathrm{mM}$ imidazole) supplemented with lysozyme (o.1 mg/mL), DNase I $(5 \mu \mathrm{g} / \mathrm{mL})$, RNase A ( $5 \mu \mathrm{g} / \mathrm{mL})$, and a protease inhibitor cocktail (Sigma). The lysate was incubated for 1 hour at room temperature. After lysis by sonication (using a 50\% duty cycle and 80\% amplitude setting on ice for $2 \mathrm{~min}$, followed by cooling on ice for $2 \mathrm{~min}$, repeated 5 times) and clearance by centrifugation at 9,500 $\mathrm{g}$ and $25^{\circ} \mathrm{C}$ for $25 \mathrm{~min}$, the supernatants were loaded onto $1.5 \mathrm{~mL} \mathrm{Ni}$ (II)-NTA sepharose resin (50\% v/v, Qiagen) pre-equilibrated with $30 \mathrm{~mL}$ lysis buffer in a gravity flow column. After washing with $40 \mathrm{~mL}$ wash buffer ( $50 \mathrm{mM}$ sodium phosphate ( $\mathrm{pH} 8.0$ ), $800 \mathrm{mM} \mathrm{NaCl}$ ) containing $20 \mathrm{mM}$ and $40 \mathrm{mM}$ imidazole, AaLS-13ABD was eluted with $15 \mathrm{~mL}$ lysis buffer containing $500 \mathrm{mM}$ imidazole. The buffer was exchanged to AaLS storage buffer (50 mM sodium phosphate buffer ( $\mathrm{pH} 8.0$ ), $200 \mathrm{mM} \mathrm{NaCl}, 5 \mathrm{mM}$ EDTA) using an Amicon Ultra-15 centrifugal filter unit (3o kDa MWCO) (Merck Millipore). After the buffer was exchanged, a $5 \mathrm{M} \mathrm{NaCl}$ solution was added (10\% by volume) to the concentrated AaLS-13ABD sample to give a final $\mathrm{NaCl}$ concentration of $600 \mathrm{mM}$, the mixture was incubated at room temperature for 5 days to complete cage formation. The AaLS-13ABD cages were then purified by size-exclusion chromatography (SEC) using a Hi-prep Sephacryl 400 column (GE Healthcare). The purified AaLS-13ABD cages were stored at room temperature. The concentration of AaLS-13ABD was determined by absorbance at $280 \mathrm{~nm}(\varepsilon 280=15,470$ $\left.\mathrm{M}^{-1} \mathrm{~cm}^{-1}\right)$. 


\section{Cell culture}

SKBR-3 and SKOV-3 cells were maintained in McCoy's 5A medium (Sigma M8403). MCF-7 cells were maintained in Iscove's modified Dulbecco's medium (Sigma I3390). In all cases, media were supplemented with 10\% fetal bovine serum (FBS), 2 mM L-glutamine, $2 \mathrm{mM}$ GlutaMAX, and $1 \mu \mathrm{g} / \mathrm{mL}$ gentamicin. Cells were seeded at $1 \times 10^{6}$ cells per $\mathrm{T}_{75}$ flask and allowed to grow for $3^{-4}$ days at $37^{\circ} \mathrm{C}$ in $5 \% \mathrm{CO}_{2}$.

\section{Antibody binding and purification}

AaLS-13ABD or AaLS-13 cages (10 $\mu \mathrm{M})$ were mixed with different amounts (10, 50 or 100 per cage) of carboxyfluorescein-labeled mouse serum IgGs in AaLS storage buffer. Each sample was incubated in a $1.5 \mathrm{~mL}$ Eppendorf tube covered with aluminum foil for 1 hour at $25^{\circ} \mathrm{C}$ and at $650 \mathrm{rpm}$. The samples were then loaded onto $0.5 \mathrm{~mL}$ of $\mathrm{Ni}(\mathrm{II})-\mathrm{NTA}$ sepharose resin (50\% v/v, Qiagen) pre-equilibrated with $6 \mathrm{~mL}$ equilibration buffer (50 mM sodium phosphate (pH 8.o), $300 \mathrm{mM} \mathrm{NaCl}, 10 \mathrm{mM}$ imidazole) in a gravity flow column. After washing with $6 \mathrm{~mL}$ washing buffer ( $50 \mathrm{mM}$ sodium phosphate ( $\mathrm{pH} 8.0$ ), $800 \mathrm{mM} \mathrm{NaCl}$ ) containing $20 \mathrm{mM}$ and $40 \mathrm{mM}$ imidazole, AaLS-13ABD and AaLS-13 cages were eluted with $5 \mathrm{~mL}$ equilibration buffer containing $500 \mathrm{mM}$ imidazole. The samples were concentrated and the buffer was exchanged to AaLS storage buffer (5o mM sodium phosphate buffer (pH 8.o), $200 \mathrm{mM} \mathrm{NaCl}, 5 \mathrm{mM}$ EDTA) using an Amicon Ultra15 centrifugal filter unit (3o kDa MWCO) (Merck Millipore).

\section{Cellular uptake by flow cytometry}

Cells were seeded at a density of 100,ooo cells per well (SKBR-3 and SKOV-3) or 50,0oo cells per well (MCF7) in a 24-well plate in $500 \mu \mathrm{L}$ of culture medium and allowed to recover at $37^{\circ} \mathrm{C}$ and $5 \% \mathrm{CO} 2$ for 24 hours. ATTO 565-cages, GFP(+36), and herceptin were separately sterilized by filtration through a $0.22 \mu \mathrm{m}$ membrane and individual stocks were prepared in sterile phosphate-buffered saline (PBS). The culture medium was removed and cells were washed once with $500 \mu \mathrm{L}$ Dulbecco's Modified Eagle Medium (DMEM) (Invitrogen, USA) supplemented with $1 \mu \mathrm{g} / \mathrm{mL}$ gentamicin without FBS. In each well, $90 \mu \mathrm{L}$ of sample in PBS were added to $150 \mu \mathrm{L}$ DMEM without FBS to give a final ATTO 565-labeled AaLS-13ABD concentration of $9 \mu \mathrm{M}$ with $15 \mathrm{GFP}(+36)$ and 8 herceptin antibodies per cage. Cells were incubated for 2 hours in $5 \% \mathrm{CO}_{2}$ at $37^{\circ} \mathrm{C}$ before washing with $500 \mu \mathrm{L}$ ice-cold PBS and trypsinization (0.05\% Trypsin-EDTA (Thermo Fisher Scientific), 5 minutes at $37^{\circ} \mathrm{C}$ ). Cells were collected in cold culture medium ( $500 \mu \mathrm{L} \mathrm{McCoy's} 5 \mathrm{~A}$ or Iscove's modified Dulbecco's medium) and washed twice with $5 \mathrm{~mL}$ ice-cold PBS. All centrifugation steps were carried out at $500 \mathrm{~g}$ for $5 \mathrm{~min}$ at room temperature. The cells were re-suspended in flow cytometry buffer (50o $\mu \mathrm{L}$ PBS with 3\% FBS 1 nM SYTOX Red (Thermo Fisher Scientific S34859)). SYTOX Red was used to exclude dead cells. Samples were transferred to a 5 -mL polystyrene round-bottom tube with a cell-strainer 
cap (Flacon 352235). Samples were analyzed on an LSRFortessa flow cytometer (BD Bioscences). Experiments were carried out in triplicate.

\section{Cellular uptake in serum-containing medium by flow cytometry}

SKOV-3 cells were seeded at a density of 80-100,00o cells per well in a 24 -well plate in $500 \mu \mathrm{L}$ of culture medium and allowed to recover at $37^{\circ} \mathrm{C}$ and $5 \% \mathrm{CO}_{2}$ for 24 hours. ATTO 565 -labeled cages, GFP $(+36)$, and herceptin were separately sterilized by filtration through a $0.22 \mu \mathrm{m}$ membrane and individual stocks were prepared in sterile PBS. The culture medium was removed and cells were washed once with $500 \mu \mathrm{L}$ DMEM (Invitrogen, USA) supplemented with $1 \mu \mathrm{g} / \mathrm{mL}$ gentamicin and $10 \%$ human serum or FBS. In each well, 100 $\mu \mathrm{L}$ of sample in PBS were added to $150 \mu \mathrm{L}$ of DMEM containing $10 \%$ human serum or FBS to give a final ATTO 565-labeled AaLS-13ABD concentration of $7 \mu \mathrm{M}$ with $15 \mathrm{GFP}(+36)$ and 8 herceptin antibodies per cage. Cells were incubated for 2 hours in $5 \% \mathrm{CO} 2$ at $37{ }^{\circ} \mathrm{C}$ before washing with $500 \mu \mathrm{L}$ ice-cold PBS and trypsinization (o.05\% Trypsin-EDTA (Thermo Fisher Scientific, USA), 5 minutes at $37^{\circ} \mathrm{C}$ ). Cells were collected in $500 \mu \mathrm{L}$ cold McCoy's $5 \mathrm{~A}$ medium and washed twice with $5 \mathrm{~mL}$ cold PBS. All centrifugation steps were carried out at $500 \mathrm{~g}$ for $5 \mathrm{~min}$ at room temperature. The cells were re-suspended in flow cytometry buffer (500 $\mu \mathrm{L}$ PBS with 3\% FBS 1 nM SYTOX Red (Thermo Fisher Scientific S34859)). SYTOX Red was used to exclude dead cells. Samples were transferred to a $5 \mathrm{~mL}$ polystyrene round-bottom tube with a cellstrainer cap (Flacon 352235). Samples were analyzed on an LSRFortessa flow cytometer (BD Bioscences). Experiments were carried out in triplicate.

\section{Cellular uptake by confocal microscopy}

For microscopy experiments cells were plated at 30,00o cells (SKBR-3), 22,500 cells (SKOV-3), or 15,000 cells (MCF-7) in $300 \mu \mathrm{L}$ of culture medium per well onto a $\mu$ slide 8-well chambered coverslip with ibiTreat surface from ibidi GmbH for 40 hours before confocal microscopy. One day (24 hours) after plating the cells, the medium was removed and replaced by $200 \mu \mathrm{L}$ of complete culture medium. To the cells, $15 \mu \mathrm{L}$ of sample in PBS was added to give a final ATTO 565-labeled AaLS-13ABD concentration of $1.5 \mu \mathrm{M}$ with 45 GFP(+36) and two herceptin antibodies per cage. Stocks of ATTO 565-labeled cages, GFP(+36), and herceptin were prepared in sterile PBS and additionally sterilized by filtration through a $0.22 \mu \mathrm{m}$ membrane. Cells were incubated for 16 hours at $37{ }^{\circ} \mathrm{C}$ and $5 \% \mathrm{CO}_{2}$ before washing with PBS and nuclear staining with $100 \mu \mathrm{L}$ of Hoechst 33342 solution $\left(5 \mu \mathrm{g} / \mathrm{mL}\right.$ in PBS) at $37^{\circ} \mathrm{C}$ for $10 \mathrm{~min}$. Cells were imaged by using a Visitron spinning disk confocal laser microscope equipped with stage micro incubator to keep cells at $37^{\circ} \mathrm{C}$ and $5 \%$ $\mathrm{CO} 2$. Cells were then washed twice with PBS and microscopy was carried out at $37^{\circ} \mathrm{C}$ in DMEM (Invitrogen) supplemented with $1 \mu \mathrm{g} / \mathrm{mL}$ gentamicin. Images were recorded in three laser channels (ex: $405 \mathrm{~nm}$, $488 \mathrm{~nm}$, and $561 \mathrm{~nm})$. 


\section{Stability in human serum}

AaLS-13 and AaLS-13ABD cages were mixed 1:10 with diluted human serum or FBS in AaLS storage buffer to give a final concentration of $2 \mathrm{mg} / \mathrm{mL}$ and incubated at $37^{\circ} \mathrm{C}$ for 18 hours. Control samples with serum only or protein cage only were prepared in the same way. Samples were analyzed by SEC on a Superose 6 increase column. Fractions corresponding to the intact capsids were collected and analyzed by SDS-PAGE, Western blotting, and TEM.

\section{Gel electrophoresis}

SDS-PAGE samples were prepared by adding NuPAGE 4X lithium dodecyl sulfate sample buffer (Invitrogen) according to the manufacturer's recommendations. After heating for $10 \mathrm{~min}$ at $70^{\circ} \mathrm{C}$, samples were incubated on ice for $5 \mathrm{~min}$, centrifuged for $2 \mathrm{~min}$ at $10,000 \mathrm{~g}$, and stored at $-20^{\circ} \mathrm{C}$ until use. Samples were separated on 8-16\% gradient Mini-PROTEAN TGX Precast gels (Bio-Rad) for 30 min at 200 V using a MiniPROTEAN Tetra Cell system (Bio-Rad) connected to a programmable PowerPac Basic (Bio-Rad) power supply. A commercially available pre-stained $10-180$ kDa protein ladder (Thermo Fisher) was used as a molecular weight marker. Gels were stained with Coomassie (o.1\% Coomassie Brilliant Blue R, 40\% MeOH, $10 \%$ acetic acid) with gentle agitation for 1 hour, followed by destaining ( $40 \% \mathrm{MeOH}, 10 \%$ acetic acid), and imaging on a Bio-Rad ChemiDoc MP Imaging System.

\section{Western blotting}

Samples were separated by SDS-PAGE and transferred to polyvinylidene difluoride (PVDF) membranes using a Trans-Blot Turbo Transfer System (both BioRad). Membranes were blocked with 5\% non-fat dried milk in PBS containing 0.05\% Tween 20 (PBS-T) for 2 hours at room temperature and then incubated for 2 hours with HRP-conjugated mouse anti-human IgG Fc (Southern Biotech 9042-05) at a dilution of 1:5000 in $5 \%$ milk in PBS-T. Membranes were washed three times for 5 min with PBS-T, developed using Clarity Western ECL chemiluminescence substrate (Bio-Rad), and imaged on a Bio-Rad ChemiDoc MP Imaging System.

\section{Immunogenicity}

The stimulation of AaLS-13ABD and AaLS-13-specific antibody responses was studied in BALB/c mice immunized with the respective cages by intravenous administration of the proteins via the tail vein. Doses of $0.2 \mu \mathrm{g}$ or $1 \mu \mathrm{g}$ protein in $100 \mu \mathrm{L}$ sterile PBS were injected on days 0,16 , and 38 , and blood was collected on days $14,29,52$, and 72 for preparation of serum, which was stored at $-20{ }^{\circ} \mathrm{C}$ until analysis by enzyme-linked immunosorbent assay (ELISA). MaxiSorp plates (96-well, Sigma) were coated overnight with $100 \mu \mathrm{L}$ of 1 $\mu \mathrm{g} / \mathrm{mL}$ protein in $50 \mathrm{mM}$ carbonate/bicarbonate buffer $(\mathrm{pH} 9.6)$ at $4{ }^{\circ} \mathrm{C}$. The next day, the plates were 
washed three times with PBS containing 0.05\% Tween 20 (PBS-T) and blocked with $150 \mu \mathrm{L}$ of $5 \%$ non-fat dried milk in PBS-T for 2 hours at room temperature. Then, serial dilutions of $50 \mu \mathrm{L}$ sera in PBS-T with milk were added to the wells, and the plates were incubated overnight at $4{ }^{\circ} \mathrm{C}$. After washing the plates three times with PBS-T, $50 \mu \mathrm{L}$ (1:100o dilution in PBS-T with milk) biotinylated anti-murine antibodies (goat polyclonal antibodies to mouse IgG1, IgG2a and IgG2b from Abcam ab97238, ab97243, and ab97248) were added to each well and the plates incubated for 2 hours at room temperature. Plates were washed three times with PBS-T before adding $50 \mu \mathrm{L}$ (1:100o dilution in PBS-T with milk) streptavidin-conjugated HRP per well (Biolegend 405210). After a 2-hour incubation at room temperature, plates were washed 4 times with PBS-T and developed with $50 \mu \mathrm{L}$ per well tetramethyl benzidine (TMB) substrate set (Biolegend 77247 and 77248 ) for 5 min at room temperature. The enzymatic reaction was stopped by adding $25 \mu \mathrm{L}_{2} \mathrm{~N} \mathrm{H}_{2} \mathrm{SO}_{4}$ to each well. The absorbance at $450 \mathrm{~nm}$ was measured using a microplate reader.

\title{
Protein sequences
}

Molecular weights $(\mathrm{MW})$, isoelectropoints $(\mathrm{pI})$, and extinction coefficients at $280 \mathrm{~nm}\left(\varepsilon 280, \mathrm{M}^{-1} \mathrm{~cm}^{-1}\right) \mathrm{of}$ proteins were calculated using the SIB Bioinformatics Resource Portal tool (http://web.expasy.org/protparam/).

AaLS-13 (162 residues, MW = 17,684.01, pI = 4.96, $\varepsilon_{280}=13,980$ )

\begin{abstract}
MEIYEGKLTAEGLRFGIVASRFNHALVGRLVEGAIDCIVRHGGREEDITLVCVPGSWEIPVAAGELARKE DIDAVIAIGVLIEGAEPHFDYIASEVSKGLANLSLELRKPISFGDITDDELEEAIECAGTEHGNKGWEAAL SAIEMANLFKSLRLEHHHHHH
\end{abstract}

AaLS-13ABD (223 residues, MW = 24,535.58, pI = 4.99, $\varepsilon_{280}=15,470$ )

MEIYEGKLTAEGLRFGIVASRFNHALVGRLVEGAIDCIVRHGGREEDITLVCVPGSWEIPVAAGELARKE DIDAVIAIGVLIEGAEPHFDYIASEVSKGLANLSLELRKPISFGDITDDELEEAIECAGTEHGNKGWEAAL SAIEMANLFKSLRLEHHHHHHAAAVDNKFNKEQQNAFYEILHLPNLNEEQRNAFIQSLKDDPSQSAN LLSEAKKLNDAQAPK

$\operatorname{GFP}(+36)\left(249\right.$ residues, $\left.\mathrm{MW}=\mathbf{2 8 , 6 5 1 . 3 5}, \mathrm{pI}=10.42, \varepsilon_{280}=18,910, \varepsilon_{488}=36,600\right)$

MHHHHHHGSGMASKGERLFRGKVPILVELKGDVNGHKFSVRGKGKGDATRGKLTLKFICTTGKLPV PWPTLVTTLTYGVQCFSRYPKHMKRHDFFKSAMPKGYVQERTISFKKDGKYKTRAEVKFEGRTLVNRI KLKGRDFKEKGNILGHKLRYNFNSHKVYITADKRKNGIKAKFKIRHNVKDGSVQLADHYQQNTPIGR GPVLLPRNHYLSTRSKLSKDPKEKRDHMVLLEFVTAAGIKHGRDERYK

\section{References}

(1) Azuma, Y., Zschoche, R., Tinzl, M., and Hilvert, D. (2016) Quantitative Packaging of Active Enzymes into a Protein Cage. Angew. Chem. Int. Ed. Engl. 55, 1531-1534. 
(2) Sasso, S., Ramakrishnan, C., Gamper, M., Hilvert, D., and Kast, P. (2005) Characterization of the secreted chorismate mutase from the pathogen Mycobacterium tuberculosis. FEBS J. 272, 375-389. 